\title{
Greek Fish Farming: Measuring Profitability and Efficiency of the Sector at the peak of Economic Crisis
}

\author{
ATHANASIA MAVROMATTI \\ Department of Business Administration of Food and Agricultural Enterprises \\ University of Patras \\ Agrinio, 30100 \\ GREECE \\ ACHILLEAS KONTOGEORGOS \\ Department of Agricultural \\ International Hellenic University \\ Sindos, Thessaloniki, 57400 \\ GREECE \\ FOTIOS CHATZITHEODORIDIS \\ Department of Regional and Cross-Border Development \\ University of Western Macedonia \\ Kozani, 50100 \\ GREECE
}

\begin{abstract}
Fish farming play important role in providing food and income in many EU countries, either as a standalone activity or in association with crop agriculture and livestock rearing. Fish farming is widespread in Greece and differs only with respect to species, production systems and volumes. Moreover, the Greek economic crisis has heavily affected the fish farming sector and challenges the competitiveness of farms. The objective of the current paper is the examination of the profitability and efficiency of the Greek fish farming industry during the most crucial years of Greek economic crisis by measuring firm's performance using a panel data set of companies. The research is based on financial data of sixty-eight aquaculture firms for the period 2010-2015. The empirical results indicate that firms share of total sales has a positive impact on profitability, while an alternative proxy, the total assets is negatively linked to efficiency. Firm's profitability is positively affected by liquidity, working capital management, productivity and industry's growth and negatively by financial and operating leverage. Firms Efficiency is determined positively by profitability and ability to repay its debt obligations and negatively by capital intensity, operating leverage and size.
\end{abstract}

Key-Words: Profitability, efficiency, panel data, fish farming, economic

Received: February 2, 2021. Revised: September 1, 2021. Accepted: September 14, 2021. Published: September 29, 2021.

\section{Introduction}

The Greek economy in recent years faced a major debt crisis and recession that lasted ten years [1]. During 2010, the Greek government pledged to reduce its budget deficit through the implementation of a series of austerity measures due to the agreement with the International Monetary Fund, the European Central Bank and the European Commission [2]. This austerity program and the dynamics of the financial crisis and recession during the period 2009-2017 caused the cumulative decline of the country's GDP, the reduction of consumption and the dramatic increase of unemployment, who they led to a reduction of domestic demand. The recession in 2011 led to a reduction in investment of about $20 \%$ and affected all sectors of business [3,4] as companies found themselves at a dead end due to lack of liquidity in the Greek market. Only a few sectors of the Greek economy managed to escape from this instability cycle, especially those with an export orientation or those sectors that managed to start exporting under the pressure of shrinking domestic demand $[5,6]$. One of these sectors was the Greek aquacultures. 
Marine fish farming in Greece was established in the early 1980s motivated by the strong European Union (EU) support in establishing pilot-scale farms [7]. Fish farming is an important and promising sector of the Greek economy. Fish farming in Greece represents $84 \%$ in terms of volume and $98 \%$ in terms of value of the total aquaculture production, while is the third fish farming producer in the world, and the first in the European Union. The sector is oligopolistic, with the eight largest Greek companies to concentrate the approximately $80 \%$ of the aggregate sales, benefiting from economies of scale in production, while they hold a stable share, greater than $45 \%$, of the EU-27 production. The Greek aquaculture industry is highly export-oriented and contributes about $11 \%$ of the total national agricultural exports, while employs directly and indirectly approximately 12,000 persons. The $80 \%$ of total production takes place in Peloponnese, Thessaly and Central Greece, Western Greece and the Ionian Islands and the Aegean [8].

The present study aims to investigate the potential key drivers of firms' profitability and efficiency in the Greek aquaculture industry at the peak of Greek economic crisis (2010-2015). More specifically, seeks to ascertain how these determinants influence the profitability and competitiveness of the Greek fish farming companies. According to many studies $[9,10,11,12]$ the most commonly used indicators of a firm's competitiveness are the operating performance, market performance and profitability. Operational ability and profitability are mainly determined by productivity, cost efficiency, size, competitive prices, capital investment, product quality, flexibility, and leverage among others [11, $12,13,14]$.

Numerous studies examine the relationship between firms' performance, using different measures of performance, while employing different statistical tests and econometric approaches $[12,15,16,17,18]$. Increased market share is determined by the firm's ability and capability of creating and sustaining market values, such as competitive advantages [19]. Profitability is associated with competitiveness, especially in fish sector where costs are essential in determining prices and the world competition is based mainly on that. There is a large literature identifying factors affecting profitability in fish farming sector, while relate financial performance to several explanatory factors such as, market share, financial and operating leverage, size, age, capital investment, working capital among others $[12,16,20$, 21, 22, 23 24].

Technical efficiency reflects the ability of a firm to obtain maximum outputs from a given set of inputs.
The majority of the studies that measure efficiency use the Data Envelopment Analysis (DEA) or Stochastic Frontier Analysis and investigate the extent to which a firm that uses several inputs and produces several outputs, is efficient in the way it allocates its resources [25, 26, 27]. The stochastic frontier approach is considered more appropriate for assessing technical efficiency in a developingcountry agriculture, where data are often heavily influenced by measurement errors [28, 29, 30, $31,32,33,34]$. In recent studies, econometric models have been used to investigate technical efficiency effects because of the computational simplicity and ability to examine the effect of various farm-specific variables $[11,30,35,36]$. The paper is organized as follows: section two presents the methodology, section three presents the results, section the discussion, and finally section five sums up with the conclusions.

\section{Methodology}

Panel data econometric approach was applied to find the variables that explain the variations of firms' profitability and efficiency during study period. Annual data is preferable in order to avoid seasonality problems which are dominant in this sector. The conjunction of time series and crosssectional data allows for higher degrees of freedom in the estimation process, gives more data information, reduces the multicollinearity effects, and allows for dynamic specification. Two econometric models were constructed, the first one measures profitability, while the second measures technical efficiency. The robustness of the sample is highly indicated by the inclusion of the firms with the higher profitability and sales share of the market, approaching approximately the $90 \%$ of the total share of the Greek fish sector in the period under consideration. In the accounting literature, firm's profitability is defined as the operational margin before financial costs and taxes, which are irrelevant to the extra operational activity $[37,38]$. Technical efficiency reflects the ability of a firm to obtain maximum outputs from a given set of inputs and is measured by Total Sales/Fixed Assets.

In this study sixty-eight companies from Greek fishery sector were considered and the financial data used were obtained from the ICAP Hellas for the period 2010-2015. Although, according to the literature the fish farming efficiency investigation is mainly based on DEA and Stochastic Frontier Analysis, the current empirical analysis uses the Panel data method to identify the relationship between firms' financial attributes and level of profitability-efficiency. The econometric approach 
assists to the detection of the differences in profitability-efficiency caused by the management of resources of the firms, emphasizing on the managerial capability, along with size, operating leverage and age.

In the present study, the term "panel data" refers to the pooling of observations in a cross-section of the 68 companies over a period of six years (2010-2015). Panel data can be balanced when all entities are observed in all time periods. The main three types of panel-data models are pooled Ordinary Least Squares (OLS) model (assumes constant coefficients), fixed effects model (assumes that the individual specific effects are correlated with the regressors), and random effects model (assumes that the individual specific effects are not correlated with the regressors). The combination of cross section and time series data should be conducted in an appropriate statistical way, otherwise the coefficients will not be efficient. In order to decide between fixed or random effects we run a Hausman test where the null hypothesis is that the preferred model is random effects vs. the alternative fixed effects [39].

The following theoretical models are used in order to estimate Profitability and Efficiency in Greek Fish farming industry.

$$
\begin{aligned}
& P R F_{i t}=c_{i}+b_{1} M S_{i t}+b_{2} A G E_{i t}+b_{3} G R I_{i t}+b_{4} P R O D_{i t}+b_{5} F I N_{i t}+b_{6} W C T A_{i t}+ \\
& +b_{7} O P E R_{i t}+b_{8} L I Q_{i t}+u_{i t} \\
& E F F_{i t}=c_{i}+b_{1} S I Z E_{i t}+b_{2} A G E_{i t}+b_{3} E B I T_{i t}+b_{4} C A P_{i t}+b_{5} O P E R_{i t}+b_{6} P R F+u_{i t}
\end{aligned}
$$

where $\mathrm{i}$ refers to cross sections and $\mathrm{t}$ refers to time periods, where $u$ it is an error term.

- PRF: Measure profitability and is defined as the operational margin before financial costs and taxes, which are irrelevant to the extra operational activity [36]. PRF is used as depended variable in the first model. Furthermore, PRF is used as explanatory variable in the model that measures efficiency and is expected to have positive effect [11, 40].

- EFF: Measures technical efficiency and is taken as Total Sales /Fixed Assets. EFF is used as depended variable in the second model.

- MS: Is the market share, which is the proportion of demand that each firm covers in the market and is used as explanatory variable in the first model. Market share is measured by the formula: MS=FTSt/ITSt, where FTSt is the firm's total sales for a certain year and ITSt is industry's total sales for the same year. We expect that market share has a positive influence on profits; that is, an increase in market share would provide the incentive in firms to increase their profitability [42, 43].

- AGE: Age measured as year $t$ minus year of firm's establishment. AGE is used as explanatory variable in both models and is expected to affect profitability positively and the efficiency negatively [11].

- GRI: Is the industry's sales growth rate, measured as the annual percentage change of the total sales and is used as explanatory variable in the first model. It is suggested in the literature $[44,45,46]$ and has a positive effect on profits. GRI is calculated by the formula: GRI $=$ (TstTst-1)/Tst-1, where Tst is the total sales of a certain year and Tst- 1 is the total sales of the previous year.

- PROD: Productivity is measured in terms of Total Sales/number of employees. Is used as explanatory variable in the first model and the literature has shown that affects profitability positively [11, 47]. Profitable firms are those that are more productive and cost effective in their operations and management [48].

- FIN: Is the financial leverage and is measured by Long Term debt/Total Assets. Financial leverage is used as independent variable in the first model and is shown to have negatively impact performance in the general literature [12].

- WCTA: Is measured as Working Capital/Total Assets; We expect that capital investment has a positive influence on profits; that is, an increase in WCTA would provide the incentive in firms to increase their profitability [21]. Firms in fish industry need a significant level of working capital to generate sales.

- LIQ: Is liquidity ratio (Current Assets/Current Liabilities) and is used as explanatory variable in the first model. The liquidity ratio is expected to have a positive effect on profitability. High liquidity ratio lowers the risk of being unable to meet short-term financial commitments [10].

- OPER: Is the operating leverage as a proxy for the mixture of fixed and variable cost [49]. Firms with high operating leverage normally experience higher variability in profitability than firms with low operating leverage. These firms are observed to perform better than average in good times, and below average in worse times [12]. Is used as explanatory variable in both models and is expected to affect profitability and efficiency negatively. 
- SIZE: Size is measured by firm's Total Assets. This measure is used as explanatory variable in the second model and is expected to affect efficiency negatively [11].

- EBIT: Is the ability of each company to pay its fixed obligations or interest coverage ratio. Is measured as EBIT/interest expense and lease obligations, used as a proxy of financial risk in the firm (EBIT: Earnings Before Interest and Taxes). This variable is used in the second model and is expected to affect efficiency positively [11].

- CAP: Is measured as Fixed Assets/Total Assets and it shows the firm's capital intensiveness. This measure is used as independent variable in the second model and is expected to affect efficiency negatively $[11,50]$.

\section{Results}

The regression results of pooled OLS and fixed effect estimator are shown in Table 1 and give the estimated coefficients for the first panel data set that measure profitability. The explanatory power of the Greek fish farming profitability regression is quite high ( $\mathrm{R}$ squared $=0.78$ ). According to the results displayed, all of the variables have the expected signs and most of the variables have the expected level of significance. A series of t-test at $1 \%$ and $5 \%$ level of significance have been applied on each independent variable against the dependent variable. From the above panel model equation, PROD and LIQ, share the same level of significance, which is $1 \%$. MS, GRI, FIN, WCTA and OPER are statistically significant at 5\%. Only AGE variable was non-significant (see table 1).

Table 1, Pooled OLS regression/Fixed Effect model estimation of Profitability

\begin{tabular}{lcccc}
\hline \hline & \multicolumn{2}{c}{ OLS Regression } & \multicolumn{2}{c}{ Fixed Effect Model } \\
\hline \hline & Coefficient & Prob.- Value & Coefficient & Prob.- Value \\
C (constant) & 195.32 & 0.050 & 117.48 & 0.045 \\
MS & 0.1325 & 0.014 & 0.1725 & 0.001 \\
AGE & 2.3521 & 0.195 & 2.7563 & 0.184 \\
GRI & 0.1365 & 0.016 & 0.1891 & 0.008 \\
PROD & 197.42 & 0.000 & 168.12 & 0.000 \\
FIN & -161.43 & 0.024 & -158.62 & 0.020 \\
WCTA & 94.271 & 0.004 & 75.962 & 0.000 \\
OPER & -0.6852 & 0.008 & -1.9412 & 0.000 \\
LIQ & 0.3223 & 0.000 & 0.3711 & 0.000 \\
Observations & 408 & & 408 & \\
\hline & $\mathbf{R}^{2}$ & $\mathbf{0 . 8 4}$ & $\mathbf{R}$-sq (overall) & $\mathbf{0 . 7 8}$ \\
& $\mathbf{R}^{2}$ Adjusted & $\mathbf{0 . 8 2}$ & $\mathbf{F}(\mathbf{8}, \mathbf{3 3 2})$ & $\mathbf{1 9 . 2 5}$ \\
& F-Statistic & $\mathbf{0 . 8 8}$ & Prob > F & $\mathbf{0 . 0 0 0}$ \\
& & & rho & $\mathbf{0 . 8 4 7 5}$ \\
\hline
\end{tabular}

Source: Authors' own work, 2021.

The regression results of pooled OLS and fixed effect estimator are shown in Table 2 and give the estimated coefficients for the second panel data set that measure efficiency. The explanatory power of the Greek fish farming efficiency regression is quite high ( $R$ - squared=0.72). According to the results displayed, most of the variables have the expected signs and the expected levels of significance. A series of t-test at $1 \%$ and $5 \%$ levels of significance have been applied on each independent variable against the dependent variable. From the above panel model equation, CAP is statistically significant at $1 \%$. SIZE, EBIT, OPER and PRF are statistically significant at 5\%. Only AGE was non-significant. (see table2)

Table 2, Pooled OLS regression/Fixed Effect model estimation of Efficiency

\begin{tabular}{lcccc}
\hline \hline & \multicolumn{2}{c}{ OLS Regression } & \multicolumn{2}{c}{ Fixed Effect Model } \\
\hline \hline & Coefficient & Prob.- Value & Coefficient & Prob.- Value \\
C (constant) & 43.778 & 0.000 & 52.184 & 0.000 \\
SIZE & -0.0025 & 0.048 & -0.0031 & 0.036 \\
AGE & 0.6715 & 0.182 & 0.9821 & 0.167 \\
CAP & -91.587 & 0.000 & -111.42 & 0.000 \\
EBIT & 0.0026 & 0.042 & 0.0036 & 0.038 \\
OPER & -0.0086 & 0.028 & -0.0092 & 0.017 \\
PRF & 0.0523 & 0.012 & 0.6252 & 0.009 \\
Observations & 408 & & 408 & \\
\hline \hline & $\mathbf{R}^{2}$ & $\mathbf{0 . 8 8}$ & R-sq (overall) & $\mathbf{0 . 7 2}$ \\
& $\mathbf{R}^{2}$ Adjusted & $\mathbf{0 . 8 6}$ & $\mathbf{F}(\mathbf{6}, \mathbf{3 3 4})$ & $\mathbf{1 9 . 2 8}$ \\
& F-Statistic & $\mathbf{0 . 8 7}$ & Prob > F & $\mathbf{0 . 0 0 0}$ \\
& & & rho & $\mathbf{0 . 8 2 6 6}$ \\
\hline
\end{tabular}

Source: Authors' own work, 2021.

The application of the Hausman-test for fixed effects or random effects in the study shows that the fixed effect model is the advisable estimation method for the two models.

\section{Discussion}

The results from the profitability model, shown in Table 1, are in line with the general literature which reports that the market share positively and significantly influences firms profitability. Larger firms as expected have higher profitability, since they can achieve lower cost per unit in line with the economies of scale. The operating leverage negatively impacts profitability; however, the ratio between working capital and total assets positively impacts profitability. In this highly cyclical industry, it was expected that firms with a more flexible cost structure (a lower share of fixed assets) adapt better to changing business condition and therefore perform better [12]. Also, financial leverage has a negative effect on profitability. This can be considered as a reasonable result, since it is clear that greater borrowing implies a reduction of profitability [51, 52]. Obviously, this rule also applies to fishery firms in Greece. Liquidity ratio and productivity have a positive, statistically significant, effect on profitability. Productivity gives rise to comparative advantage and greater potential for investment, while empirical research has found that productivity is the key variable explaining profitability [53]. Impact of market growth also shows a strong and positive association with profitability. As reported in Table 1, 
for these fish farming companies age is not found to significantly affect profitability.

The results from the efficiency model, which is reported in Table 2, indicate that total assets as a proxy of firms size negatively and significantly influences efficiency, which indicates that in fish sector firms with small amounts of total assets perform better than their counterparts. Coefficient of the size reflects how firm's efficiency changes with the company's expansion. The larger the company, the lower the efficiency. The results also suggest that efficiency is positively affected by firm's profitability and ability to repay its debt obligations. This means that those fish farming firms which are able to repay their debts have credibility and a healthy financial condition and can attain higher efficiency in fixed assets. Furthermore, operating leverage and capital intensity are found to be negatively related to fixed assets efficiency. This means that, combined with size, small size firms with low investments in fixed assets are the ones that can be more efficient in terms of productive assets. As reported in Table 2, for these fish farming companies age is not found to significantly affect technical efficiency.

The current study indicates that although Greek aquaculture is mature, at least compared to other countries in Europe, there is still much that can be done to improve the efficiency and profitability of Greek fish farms. Simple messages such as improving production cost and feeding practices can have a significant impact on farm profitability, transforming aquaculture businesses from just surviving into thriving, profitable enterprises. High use of working capital decreases productivity, acting as an indication of low managerial capability in the use of firm's funds. The high prices of inputs affect the economic performance of farms adversely. The low producer prices cannot counterbalance income losses from the increased production cost and the uncertain overall economic environment. In this industry it was expected that firms with a more flexible cost structure and with low shares of fixed assets, adapt better to changing business condition and therefore perform better [12].

\section{Conclusion}

The Greek fish farming industry is an important sector in terms of its total manufacturing output, growth and profitability even if the economy is under instability, like in the previous decade. A panel data analysis is used to identify the most significant variables of firms' profitability and efficiency for eighty-six Greek fish farming companies for the period 2010- 2015 where the Greek economy was at the peak of the crisis. The empirical results from investigating a large sample of Greek firms in fish industry sector suggest that firm market share, sector growth, liquidity, productivity and working capital influence firm's profitability positively, while firms operating, and financial leverage influences it negatively. Furthermore, the empirical results suggest that firm's size, operating leverage and capital intensity influence efficiency negatively, while profitability and firm's ability to repay its debt obligations influences it positively.

The above results suggest that policies at national or firm level for the growth of profitability of the fish farming sector should be focused on the improvement of the firms efficiency in terms of their investment conditions management, as well as on the improvement of the economies of scale (degree of growth). Managers of fish farming companies in Greece should efficiently use their resources and control of production expenses. They should make reasonable use of debt, retaining company's financial risk at low level. In fish farming sector, companies with more flexible cost structure and low shares of fixed assets, adapt better to changing business conditions and, therefore, perform better. The results of this research can contribute to the benefit of fish farming companies, considering that capital investments have an important role in their sustainable development. They can be used by managers as a helpful tool while making strategic and investment decisions. Special attention should be given by the State in fish farming sector, to support the economy and achieve economic growth because this sector has been proved that remains stably positive at edged economic circumstances. Greece is an economy in crisis in high need of exports and fishery sector can help in increasing the country's exports, contributing to its GNP growth and job creation.

\section{References:}

[1] Chatzitheodoridis, F., Kontogeorgos, A. \& Loizou, E., The Lean Years: Private Investment in the Greek Rural Areas, Procedia Economics and Finance, Vol.14, 2014, pp. 137-146 (doi:10.1016/S2212-5671(14) 00695-9).

[2] Kontogeorgos, A., Pendaraki, K. \& Chatzitheodoridis, F, Economic Crisis and Firms' Performance: Empirical Evidence for The Greek Cheese Industry, Revista Galega de Economía, Vol. 26, No.1, 2017, pp. 73-82.

[3] Bourletidis, K., The strategic management of market information to SMEs during economic crisis, Procedia - Social and Behavioural Sciences, Vol. 73, 2013, pp. $598-606$. 
[4] Voulgaris, F., Agiomirgianakis. G. \& Papadogonas, T., Job creation and job destruction in economic crisis at firm level: the case of Greek manufacturing sectors, International Economics and Economic Policy, Vol. 12, 2015, pp. 21-39.

[5] Chatzitheodoridis, F., Michailidis, A., Theodosiou, G. \& Loizou, E., Local Cooperation: A Dynamic Force for Endogenous Rural Development, Contributions to Economics, Vol. 3, 2013, pp. 121-132

[6] Kontogeorgos, A, Chatzitheodoridis F, \& Loizou, E., Adaptation Strategies for the Greek Agricultural Cooperatives during the Economic Crisis, Agricultural Economics, Vol. 62, no.1, 2016, pp. 26-34 (doi:10.17221/22/2015AGRICECON).

[7] Theodorou, J.A., Perdikaris, C. \& Filippopoulos, N.G., Evolution through innovation in aquaculture: a critical review of the Greek mariculture industry, Journal of Applied Aquaculture, Vol. 27, No.2, 2015, pp. 160-181.

[8] FAO - Food and Agriculture Organization of the United Nations, Greece: National Aquaculture Sector Overview, 2020. http://www.fao.org/fishery/countrysector/ naso_greece/en

[9] Peteraf, M.A, The cornerstones of competitive advantage: a resource-based view, Strategic Management journal, Vol. 14, No.3, 1993, pp.179-191.

[10] Goddard, J., Tavakoli, M. \& Wilson, J. O., Determinants of profitability in European manufacturing and services: Evidence from a dynamic panel model, Applied Financial Economics, Vol. 15, No.18, 2005, pp. 12691282.

[11] Voulgaris, F. \& Lemonakis, C., Productivity and efficiency in the agri-food production industry: the case of fisheries in Greece, Procedia Technology, Vol. 8, 2013, pp. 503-507.

[12] Asche, F., Sikveland, M. \& Zhang, D., Profitability in Norwegian salmon farming: The impact of firm size and price variability, Aquaculture Economics and Management, Vol. 22, No.3, 2018, pp. 1-12.

[13] Zhang, D. \& Zheng, Y., The role of price risk in China's agricultural and fisheries exports to the US, Applied Economics, Vol. 48, No.41, 2016, pp. 3944-3960.

[14] Grozdi 'c, V., Mari'c, B., Radiši'c, M., Šebestová, J. \& Lis, M., Capital investments and manufacturing firms' performance: Panel-data
Analysis, Sustainability, Vol.12, No.4, 2020, 1689.

[15] Capon, N., Farley, J. U. \& Hoenig, S., Determinants of financial performance: A metaanalysis, Management Science, Vol. 36, No.10, 1990, pp. 1143-1159.

[16] Hirsch, S. \& Schiefer, J., What causes firm profitability variation in the EU food industry? A redux of classical approaches of variance decomposition, Agribusiness, Vol. 32, no.1, 2016, pp. 79-92.

[17] Sandvold, H. N. \& Tveterås, R., Innovation and productivity growth in Norwegian production of juvenile salmonids, Aquaculture Economics \& Management, Vol. 18, no.2, 2014, pp. 149-168.

[18] Ester, T. \& Ballkoc, V., Capital Expenditure and Firm Performance Evidence from Albanian Construction Sector, European Scientific Journal, Vol. 13, 2017, pp. 231-238

[19] Karakitsiou A. \& Mavrommati, A., Measuring large firm's profitability with panel data models. Application to Greek food industry, Journal of Financial Decision Making, Vol. 5, no.2, 2009, pp. 111-120.

[20] Agnarsson, S., A Non-Parametric study of the performance of the Icelandic fish processing industry. Economic Performance of the North Atlantic Fisheries, 2002b, M-2/2002, 2002.

[21] Deloof, M., Does working capital management affect profitability of Belgian firms? Journal of Business Finance and Accounting, Vol. 30, 2003, pp. 573-588.

[22] Grazzi, M. Nadia, J. \& Tania, T., Dynamics of investment and firm performance: Comparative evidence from manufacturing industries, Empirical Economics, Vol. 51, 2016, pp. 125179.

[23] Lei, Y., Zhao, S. X., Zheng, X. Y., \& Li, W., Effects of Fish Nets on the Nonlinear Dynamic Performance of a Floating Offshore Wind Turbine Integrated with a Steel Fish Farming Cage, International Journal of Structural Stability and Dynamics, Vol. 20, No. 3, 2020, 2050042 (31 pages)(DOI: $10.1142 / \mathrm{S} 021945542050042 \mathrm{X})$

[24] Zhang, D., Myrland, O. \& Xie, J., Firm size, commodity price and independence between firm-level stock price: The case of Norwegian salmon industry, Applied Economics and Finance, Vol. 4, no. 3, 2016, pp. 179-189.

[25] Coglan, L., Pascoe, S. \& Mardle. S., DEA versus econometric analysis of efficiency of demersal trawlers in the English Channel. In Eide, A. and Vassdal, T. (Eds); IIFET'98, Tromso 
Proceedings, Norwegian College of Fisheries Science, Tromso, pp. 334-343, 1999.

[26] Foussekis P. \& Klonaris, S., Technical efficiency determinants for fisheries: a study of trammel netters in Greece, Fisheries Research, Vol. 63, no.1, 2003 pp. 85-95.

[27] Shima, K., Lumpy capital adjustment and technical efficiency, Economics Bulletin, Vol. 30, 2010, pp. 2817-2824.

[28] Fare, S. Grosskopf \& Lovell, C.A.K., The measurement of efficiency of production, Boston: Kluwer-Nijhoff Publishing, 1985.

[29] Coelli, T.J., Rao, D.S.P. \& Battese, G.E., An Introduction to Efficiency and Productivity Analysis, Boston: Kluwer Academic Publishers, 1998.

[30] Dey, M.M., Paraguas, F.J., Srichantuk, N., Xinhua, Y., Bhatta, R. \& Dung, Le., Technical efficiency of freshwater pond polyculture production in selected Asian countries: Estimation and implication, Aquaculture Economics and Management, Vol. 9, 2005, pp. 39-63.

[31] Karagiannis, G., Katranidis, S. D. \& Tzouvelekas, V., Measuring technical, allocative and cost efficiencies of seabass and seabream farms in Greece, Aquaculture Economics \& Management, Vol. 4, No.3, 2008, pp. 191-207.

[32] Sandvold, H. N., Technical inefficiency, cost frontiers and learning-by-doing in Norwegian farming of juvenile salmonids, Aquaculture Economics \& Management, Vol. 20, No. 4, 2016, pp. 382-398.

[33] Rabiul Islam, Muhammad Fuad Othman, Aminurraasyid Yatiban, Bakri Mat, "Impact of Global Managerial Strategies on 4.0 Industrial Revolutions", International Journal of Environmental Science, 6, 2021, pp. 42-56.

[34] Ajang Sugiat, Yusuf Tojiri, "Analysis of Service Quality and Consumer Trust on Hotel Customer Satisfaction Through Online Media", International Journal of Environmental Science, 6, 2021, pp. 278-292.

[35] Sharma, K. R. \& Leung, P.S., Technical efficiency of carp pond culture in south Asia: An application of a stochastic meta-production frontier model, Aquaculture Economics and Management, Vol. 4, 2000, pp. 169-189.

[36] Simar, L. \& Wilson, P.W., Estimation and inference in two-stage, semi-parametric models of production processes, Journal of Econometrics, Vol. 136, 2007, pp. 31-64.

[37] Bottazzi, G., Secchi, A. \& Tamagni, F., Productivity, profitability and financial performance, Industrial and Corporate Change, Vol. 17, No. 4, 2008, pp. 711-751.

[38] Martin, S., Advanced Industrial Economics, Oxford: Blackwell Publishers, 1993.

[39] Carter, H.R., Griffiths, W.E., Liitkepohl, H. \& Tsounh, C.L., Introduction to the Theory and Practice of Econometrics (2nd edition). New York: John Wiley, 1988.

[40] Chen, Z., Harford, J., \& Kamara, A., Operating leverage, profitability, and capital structure, Journal of Financial and Quantitative Analysis, Vol.54, No. 1, 2019, pp. 369-392. (https://doi.org/10.1017/S0022109018000595)

[41] Shepherd, W. G., The Economics of Industrial Organisation, New Jersey: Prentice Hall, 1990.

[42] Strickland, A. D. \& Weiss, L.W., Advertising, competition and price-cost margins, Journal of Political Economy, Vol. 84, 1976, pp. 11091121.

[43] Tran, T. N., Nguyen, T. T., Nguyen, V. C., \& $\mathrm{Vu}, \mathrm{T} . \mathrm{T}$. H., Energy consumption, economic growth and trade balance in East Asian - A panel data approach, International Journal of Energy Economics and Policy, Vol. 10, no. 4, 2020, pp. 443- 449.

[44] Pagoulatos, E. \& Sorensen, R., Foreign trade, protection, and multinational activity in U.S. food Processing Industries, Southern Journal of Agricultural Economics, Vol. 11, 1979, pp. 119125.

[45] Gisser, M., Advertising, concentration and profitability in manufacturing, Economic Inquiry, Vol. 29, 1991, pp. 148-165.

[46] Grozdić, V., Marić, B., Radišić, M., Šebestová, J., \& Lis, M., (2020). Capital Investments and Manufacturing Firms' Performance: Panel-Data Analysis, Sustainability, Vol. 12, No 4, 2020, pp. 1-20.

[47] Nolle, D., An empirical analysis of market structure and import and export performance for US manufacturing industries, Quarterly Review of Economics and Business, Vol. 31, 1991, pp. $59-78$.

[48] Demsetz, H., Industry structure, market rivalry, and public policy, Journal of Law and Economics, Vol. 16, No.1, 1973, pp. 1-9.

[49] Selling, T. I. \& Stickney, C.P., The effects of business environment and strategy on a firm's rate of return on assets, Financial Analysts Journal, Vol. 45, 1989, pp. 43-68.

[50] Rao, P., Kumar, S., \& Madhavan, V., A study on factors driving the capital structure decisions of small and medium enterprises (SMEs) in India. IIMB Management Review, Vol. 31, No.1, 2019, pp. 37-50. 
[51] Satya Shah, Keotshepile Mokakangwe, Keitumetes Bose, Sarath Menon, "The Growing Adoption of Internet of Things on Supply Chains", International Journal of Economics and Management Systems, 4, 2019, pp. 108-112.

[52] Submitter, G., Sari, M., Siska, N., \& Sulastri, S., Firm Size as Moderator to Capital Structure-Its Determinants Relations. Journal of Finance and Banking Review, Vol. 4, no. 3, 2019, pp. 108115.

[53] Stierwald, A., The causes of profit heterogeneity in large Australian firms, Melbourne Institute of Applied Economic and Social Research. Working Paper No. 7/10. University of Melbourne, Melbourne, 2010.

\section{Contribution of individual authors to the creation of a scientific article}

All Authors carried out the conceptualization of the research and data collection. Athanasia Mavromatti carried out the Statistical analysis and prepared the original Draft. Achilleas Kontogeorgos, carried out the paper reviewing. Fotios Chatzitheodoridis, had the general project administration.

\section{Sources of funding for research presented in a scientific article or scientific article itself}

No funding to declare.

\section{Creative Commons Attribution}

\section{License 4.0 (Attribution 4.0 \\ International, CC BY 4.0)}

This article is published under the terms of the Creative Commons Attribution License 4.0 https://creativecommons.org/licenses/by/4.0/deed.en US 